\title{
Papież Franciszek. Jaki jest, jakim go postrzegamy? - wizerunek w przestrzeni komunikacji konfesyjnej
}

Złożona problematyka wizerunku, public relations, zarządzania sytuacją kryzysową czy choćby rzecznictwa prasowego w kontekście instytucji konfesyjnych jest już na polskim gruncie badawczym dość dobrze rozpoznana. Wydaje się jednak, że badania o charakterze analiz wizerunkowych odnoszonych do poszczególnych aktorów sceny komunikacyjnej związanej z instytucjami Kościołów i związków religijnych mają zdecydowanie mniejsze znaczenie i są raczej pomijane w zbiorach rozmaitych tego typu dociekań.

Sam w sobie problem niedostatku tego typu sfokusowanych czy spersonalizowanych badań wydaje się ciekawy. Być może jest on jakoś powiązany z pewnym lękiem przed sprowokowaniem podejrzeń, że badania tego typu i wynikające z nich wnioski mogłyby wskazywać, że instytucja konfesyjna rządzi się w swym doczesnym, ludzkim, personalnym wymiarze takimi samymi prawami jak struktury władzy, partie polityczne czy organizmy korporacyjne współczesnych firm, rynek celebrytów i gwiazd kultury popularnej. Badania takie i wywodzone z nich wnioski są oczywiście w jakiejś mierze skażone przez korekty o charakterze emocjonalnym czy ideowym respondentów - zapewne mechanizmy autocenzury działają tu mocniej niż w innych badaniach dotyczących marek i wizerunku, na pewno też wpływa na nie uwikłanie o charakterze ideologicznym i wyznaniowym, których trudno się doszukiwać w momencie prowadzenia badań o charakterze konsumenckim. Niemniej deficyt badań wizerunkowych, w tym przede wszystkim tych, które za obiekt biorą poszczególne persony aktywne w komunikacji instytucjonalnej i osobistej, wart jest szerszej 
refleksji. Poniższy tekst jest owocem badań sondażowych, które nie pretendują do miana pełnej i kompletnej refleksji dotyczącej tematyki badania wizerunku person aktywnych w komunikacji instytucji konfesyjnych. Mają one charakter próby, która nie jest miarodajna (badana grupa nie jest reprezentatywna w rozumieniu nauk społecznych). Zamysł autorski jest tu taki, aby postarać się o konfrontację pewnych założeń i konstruktów myślowych, które można wyodrębnić w komunikacji — przede wszystkim medialnej (nawet $\mathrm{w}$ większym stopniu niż wewnątrzinstytucjonalnej czy komunikacji instytucji z otoczeniem) z ewentualnym ich zakorzenianiem się (lub nie) w zestawie pojęć, ocen i skojarzeń ewokowanych w postrzeganiu społecznych respondentów.

Wybór jako obiektu badań persony Franciszka, biskupa Rzymu, zwierzchnika Kościoła katolickiego, głowy Państwa Watykańskiego, według danych osobowych Jorge Mario Bergoglio, podyktowany jest nie tylko bieżącym i aktualnym statusem pełnienia funkcji w Kościele.

Wydawać się może, że tego typu badanie mogłoby dotyczyć każdego, dowolnego zwierzchnika konfesji religijnej, w kontekście historycznym także poprzedników Franciszka na urzędzie, choćby Jana Pawła II czy Benedykta XVI. Badaniu można byłoby poddać zapewne najistotniejsze persony Kościołów lokalnych — w Polsce dla przykładu arcybiskupa Józefa Michalika, Leszka Sławoja Głodzia, kardynałów Stanisława Dziwisza czy Kazimierza Nycza (w kontekście krytycznej analizy kryzysu wizerunkowego np. arcybiskupów Juliusza Paetza, znów Józefa Michalika czy Stanisława Wielgusa). Wybór wizerunku Jorge Bergoglia podyktowany jest bardzo istotną cechą odróżniającą jego komunikację od — zdaje się — wszystkich dotychczasowych współcześnie aktywnych urzędników Kościoła katolickiego. Papież Franciszek od początku swego pontyfikatu — a jak można się zorientować z doniesień medialnych czy tekstów biograficznych jego wcześniejszej działalności poświęconych konsekwentnie rozwijanych od początku aktywności duszpasterskiej - świadomie i starannie prowadzi działania komunikacyjne, które wskazują na strategiczne budowanie pewnej znakowej i jednocześnie wypełnionej treścią komunikacji o charakterze perswazyjnym, dydaktycznym i wizerunkowym.

Franciszek zaskoczył wiernych, światową opinię publiczną, analityków i znawców tematyki watykańskiej w zasadzie już w momencie wyboru na Stolicę Piotrową i ogłaszania tej decyzji z balkonu bazyliki świętego Piotra. To wtedy zwrócił się do zgromadzonych na placu wiernych słowami „Dobry wieczór”. Pierwsze medialne przecieki, a później pełne ekscytacji relacje dziennikarskie skupiały się na szeregu symbolicznych gestów, które wykonywał Bergoglio. Wydaje się, że były one nie tylko strategicznie ułożone, prowadziły przez pewien logiczny układ do wykładu idei pełnienia roli głowy Kościoła katolickiego, lecz także ujawniły kompetencję nowego papieża w poruszaniu się w przestrzeni mediów, nie tylko promowanych czy atrakcyjnych dla nich wartości, ale przede wszystkim komunikatów, które są $\mathrm{w}$ przekazie medialnym, szczególnie elektronicznym, audiowizualnym, połączonym z przeszłym już i tyl- 
ko pogłębiającym się procesem tabloidyzacji rozumianej tu jako doszukiwanie się w komunikacie wartości ekscytacji, emocji, krótkich, wyrazistych i jednoznacznych impulsów. Franciszek potrafił także odnaleźć się w symbolice złożonej, skomplikowanej, kulturowo niezwykle trudnej do jednoznacznej i dla szerokiego grona odbiorców łatwej deskrypcji i interpretacji. Umiał, wydaje się, że bez większego trudu, niejako spontanicznie, naturalnie, bez wysiłku posłużyć się takimi strategiami, które okazywały się bardzo skuteczne, jednocześnie będąc przejrzystymi i przyciągającymi bardzo szerokie masy odbiorców.

Pierwsze wizerunkowe działania papieża Franciszka (po wyborze na Stolicę Piotrową) to łatwo dostrzegane, zwielokrotniane przez media, proste gesty symboliczne o charakterze materialnym, a jednocześnie znaczącym: rezygnacja z symboliki pontyfikalnej (tu trzeba pamiętać o jej wyraźnym dowartościowywaniu za pontyfikatu Josepha Ratzingera, który po długim i wizualnie jednak dość skromnym pontyfikacie Karola Wojtyły zaczął wyraźnie i coraz obficiej nawiązywać do przepychu symbolicznego charakteryzującego papiestwo przedsoborowe). Franciszek podjął (a także uzewnętrznił i nie dawał żadnych sygnałów, które miałyby wskazywać, że ma cokolwiek przeciw medialnemu podkreślaniu tych działań) decyzje o zamianie złotego pierścienia i krzyża na wykonane ze srebra, zrezygnował z czerwonych trzewików, które do szat pontyfikalnych nakładali na stopy poprzednicy (czerwony kolor papieskiego obuwia ma złożoną, ale też dla szerszego grona potencjalnych odbiorców trudną do rekonstrukcji symbolikę nawiązującą do motywów pasyjnych; rezygnacja $\mathrm{z}$ tego typu obuwia zapewne tę symbolikę niejako pominęła, dla większości obserwatorów była po prostu wynikiem chęci unikania osobliwości czy pewnego rodzaju „dziwności” w stroju i sposobie noszenia się głowy Kościoła, to wystarczyło jednak dla powszechnego odbioru, gest ten doceniono jako taki, który uczłowiecza papiestwo). Papież podejmował też decyzje, które dotyczyły w pierwszym rzędzie jego samego jako Jorge Bergoglia i jego jako głowy Kościoła instytucjonalnego: nie przeniósł się wraz z wyborem na Stolicę Piotrową do apartamentów papieskich zajmowanych przez poprzedników, nie zrezygnował z mieszkania, które zajmował podczas konklawe jako jeden $\mathrm{z}$ kardynałów-elektorów, nie zrezygnował ze stołowania się we wspólnej dla kardynałów stołówce, pamiętając o tym, aby zajmować miejsce w kolejce, które mu w niej z racji zwykłej kolejności przypadło. Wszystko to traktowano przez pewien czas z pobłażliwością, zaciekawieniem, licząc zapewne na to, że wkrótce zaczną się pojawiać jakieś odstępstwa, które pozwolą wytknąć Franciszkowi, że jego gesty są sztuczne, obliczone wyłącznie na poklask mediów czy że stanowią realizowaną (już niezbyt starannie i konsekwentnie) strategię wizerunkową, która ma przysłużyć się budowaniu pozytywnego wizerunku instytucji Kościoła katolickiego w mediach głównego nurtu. Staranne prowadzenie przez Franciszka działań wizerunkowych nie dawało jednak wrażenia hipokryzji czy pozerstwa. Od początku w podejmowanych działaniach Bergoglio w sposób udany łączył pewną swobodę, spontaniczność i naturalność z realizacją kompletnej strategii. 
Franciszek podejrzewany był bowiem nie tylko przez ideologicznych przeciwników, ale i szerzej przez komentatorów watykanistów o pewną sztuczność gestów czy nieodpowiedzialność w ich praktykowaniu. Można odnosić wrażenie, że kolejne działania i postawa podczas pontyfikatu niejako uwiarygodniła, przynajmniej medialnie, Jorge Bergoglio i dzisiaj nie pojawiają się już teksty, w których dziennikarze i komentatorzy rozważają stopień prawdopodobieństwa tego, że działania papieża są podyktowane wyłącznie tym, że liczy on na zdobycie poklasku konsumentów kultury liberalnej. Liczni publicyści koncentrowali się na papieskich obrazowych, jednoznacznych, wyrazistych gestach i interpretowali je jako przykłady elementarnych zagrań o charakterze wizerunkowym. Z czasem bezpośredniość Franciszka, jego duszpasterska charyzma, spłaszczanie hierarchii, budowanie relacji partnerskich, wyczulenie na sprawy biednych, wykluczonych, marginalizowanych zaczęły się wydawać elementem zwyczajnej i autentycznej praktyki Franciszka. Przysłużyła się temu niepodważalna konsekwencja i spójność mowy oraz działania, opinii, gestów i codziennej praktyki. Także wskazania, które wydawać się mogą pozorowane, formułowane na wyrost, przerzucające na innych odpowiedzialność za wcielenie słów w czyn są konsekwentnie praktykowane przez Franciszka i za każdym razem starannie dopełniane konkretnymi wymiernymi decyzjami, które blokują ewentualne zarzuty dotyczące pustosłowia ze strony zwierzchnika Kościoła katolickiego. Gdy apeluje on o dowartościowanie roli i pozycji kobiety w Kościele, wiele wysiłku wkłada w to, aby szczególnym zainteresowaniem obdarzać katolickie zakonnice. Gdy prosi, żeby pochylić się nad losem wykluczonych i migrantów, idzie spotkać się z młodocianymi przestępcami, udziela $\mathrm{w}$ obiektach watykańskich gościny rodzinom uciekającym przed przemocą z terenów objętych wojną na Bliskim Wschodzie. Prosząc o wyrozumiałość dla osób pozostających w związkach niesakramentalnych, zaprasza członków wspólnoty Kościoła do wspólnej debaty nad małżeństwem i rodziną.

Papiestwo Franciszka pokazuje (pomijam tu inne elementy, zostając wyłącznie przy komunikacyjnych, wizerunkowych i medialnych), że kwestia spójności komunikacyjnej, trafnego doboru kanałów komunikacji, pewnego rozpisania ról w dyskursie ma dzisiaj kluczowe znaczenie. Zaprojektowany wizerunek skromnego papieża komunikacyjnie rozgrywany jest $\mathrm{w}$ taki sposób, aby to nie papież sam mówił o sobie, swoich decyzjach czy niestandardowych zachowaniach. To media docierają do źródeł zbliżonych do papieża, to odbiorcy jego działań (zakonnice z jednego z klasztorów, biedni koczujący w zaułkach Rzymu, argentyński kioskarz, u którego Bergoglio opłacał prenumeratę czasopism) zwracają się do mediów (lub są przez media wyszukiwani), żeby opowiedzieć swoją historię niezwykłej bezpośredniości w kontakcie z papieżem. Pojawia się pewien konstrukt emocjonalny: dobrze być tym, który mówi światu (przede wszystkim laickiemu, im dalej oddalonemu od Kościoła, tym dla komunikacji lepiej) o niezwykłości i niekonwencjonalności tego papieża. Relacja taka jest wiarygodna, nie podlega właściwie żadnej dalszej obróbce medialnej, staje się dowodem na to, że papież działa tak, jak można wnioskować z jego gestów. 
Wspominam o tych wszystkich zdarzeniach, aby pokazać, że komunikacja papieża Franciszka wydaje się przemyślana, spójna, konsekwentna. Sprawia wrażenie (lub jest - to dla dalszych rozważań istotne, ale nieweryfikowalne) autentycznej, prawdziwej. Z drugiej strony „papież lewaków”, „uzurpator”, „oszust”, jak nazywają Franciszka publicyści związani ze skrajną konserwatywną prawicą, starannie kontroluje prawomyślność swojej teologicznej narracji, w żadnej mierze nie wychodząc poza obszar jasno i jednoznacznie nakreślonej ortodoksji. Co istotne, skutecznie neutralizuje też głosy wewnątrzkościelnej opozycji, która ustawiana jest na pozycjach oportunistycznych, dywersyjnych czy mało istotnych wobec autentycznej katolickiej debaty. Udaje się to Franciszkowi, gdy nie podejmuje dyskusji z formułowanymi przez niektórych kardynałów wezwaniami do doprecyzowania stanowiska papiestwa w kluczowych kwestiach związanych z bieżącą praktyką duszpasterską czy omijania wątpliwości przez przenoszenie problemów na wyższy poziom: debaty cywilizacyjnej, odpowiedzialności, która nie tylko spoczywa na liderze świata katolickiego, ale też aktualizuje jego kluczową pozycję w ogólnoświatowej debacie na tematy, takie jak np. ekologia i poszanowanie środowiska naturalnego.

Papież Franciszek zgrabnie lawiruje między powinnościami głowy państwa a duszpasterzem, który umiejętnie wsłuchuje się w bolączki zwykłych parafian, umie w ich imieniu definiować potrzeby, wątpliwości, zmartwienia, a jako ten, który z natury stanowiska zajmuje naczelne miejsce w hierarchii, umiejętnie potrafi operować gestami redukującymi odległość między władzą a podwładnym - dzięki temu aktualizuje bogactwo i wartości sceny duszpasterstwa jako tej, która współcześnie jest najbardziej wartościowa w pedagogice Kościoła.

W moim badaniu skoncentrowałem się na ustaleniu tego, jak komunikacja Franciszka przenosi się i odzwierciedla w kształtowanej na jego temat opinii wśród respondentów, spontanicznie udzielających odpowiedzi na pytania dotyczące postaci identyfikowanej w głównej mierze przez pryzmat komunikacji medialnej, nie przez wykład urzędu nauczycielskiego Kościoła. Interesowało mnie, czy ta komunikacja jest skuteczna nie tylko w budowaniu obrazu (konstruktu wizerunkowego) urzędującego papieża, lecz także czy ma walory informacyjne: czy respondenci są w stanie wskazać istotne dla tego pontyfikatu i niejako merytorycznej linii wypowiedzi Jorge Bergoglia tematy, czy dostrzegają podkreślane przez niego i eksponowane wątki nie tylko o charakterze duszpasterskim, wewnątrzkonfesyjnym, adresowanym do wiernych Kościoła katolickiego, ale także tych, które mogą być istotne w dyskursie ogólnym, politycznym, międzynarodowym. Ważne wydaje się także prześledzenie tego, jak obraz Franciszka jest korygowany i autokreatywnie pozycjonowany w odniesieniu do szans i zagrożeń, które przed tym pontyfikatem stoją. Tu istotne jest oczywiście wzięcie pod uwagę refleksji ogólniejszych, na przykład wynikających z dyskursu analitycznego odnoszącego się do polityki personalnej i kultury organizacyjnej urzędu administracji kościelnej (Kurii Rzymskiej), ale też poszukiwanie odpowiedzi na pytanie, na ile sam papież uznaje, że pokazywanie go jako tego, który jest samot- 
nikiem walczącym z wieloma przeciwnościami lub tym, który ma szerokie poparcie i może liczyć na pełne oddanie i lojalność ze strony otoczenia, jest decyzją strategicznie dla konstruowania wizerunku papieża kluczową.

W badaniu posługiwałem się klasycznymi narzędziami badań społecznych: ankietą anonimową realizowaną drogą internetową (zarówno otwartą przez udostępnienie w mediach społecznościowych, jak i celowaną — przez zachęcanie osób lub grup do jej wypełnienia), część ankiet została zrealizowana drogą badań terenowych (rozdawanych i wypełnianych bez kontroli prowadzącego badanie). Badanie objęło 197 respondentów. Dzięki zastosowaniu badania z pytaniami otwartymi udało się, w mojej ocenie, uzyskać bardzo interesujące dane, dające instruktywny obraz komunikacji dotyczącej głowy Kościoła katolickiego.

Prezentowane poniżej wyniki badania pokazują, jak konstruowany jest wizerunek papieża Franciszka jeszcze przed jego wizytą w Polsce (związaną ze Światowymi Dniami Młodzieży w 2016 roku), ale już po najważniejszych, symbolicznych wręcz gestach i czynach papieża, łącznie z publikacją i recepcją w dyskursie medialnym jego nauczania, w tym odnoszącego się do spraw cywilizacyjnych, relacji międzynarodowych, problematyki uchodźczej i związanego z wojną w Syrii kryzysu emigranckiego, także w obszarze ekologii.

Konstrukt „Papież Franciszek” bardzo mocno zarysowuje się u badanych jako wiele skojarzeń ewokowanych, gdy o nim myślą (pytanie: co pani/panu przychodzi na myśl, kiedy słyszy „Papież Franciszek”?), oscylujących wokół pozytywnych, ale abstrakcyjnych i ogólnych wartości: dobry, otwarty, wartości i cech wynikających z postawy i zachowania: wyrozumiały, skromny, pomaga ludziom, pomaga ubogim. Kolejnym silnie zarysowującym się obszarem skojarzeń budujących konstrukt wizerunku Franciszka są takie kategorie, jak: postęp, pogodny, lepszy od Benedykta XVI, uśmiech, dobry wybór dla zmian, reformator. Na granicy trudnej do bezkontekstualnej oceny emocjonalnej: zabawny.

Część respondentów wskazuje na kojarzące się z Franciszkiem czytelne i nagłaśniane przez media jego gesty społeczne: selfie z grupą młodych ludzi, aktywność na Facebooku czy Twitterze. Zdecydowanie rzadziej pojawiają się określenia nacechowane negatywnie, mają one też wyraźnie charakter oceny odnoszącej się do działań i ich efektów, nie samej postaci: więcej mówi niż robi; wizerunek Watykanu (tu interpretowany byłby przeze mnie jako sygnał dostrzegania postawy, działań i autokreacji jako pewnego rodzaju strategii obliczonej na manipulowanie opinią publiczną poprzez retusz nadszarpniętego wizerunku instytucji jako zamkniętej, skostniałej, trawionej skandalami finansowymi i obyczajowymi).

Dużą zbieżność odnajdujemy między autorefleksją badanych a ich projekcją na innych uczestników komunikacji. Dzięki zbadaniu tego obszaru (pytanie: co Pana/ Pani zdaniem innym ludziom przychodzi na myśl, kiedy słyszą „Papież Franciszek”?) można zrekonstruować, a także skontrolować ewentualne zmienne obyczajowe lub komunikacyjne, które zniekształcają deklaratywy odnośnie do własnej postawy i wy- 
obrażeń. Ich projekcja na innych zwykle ujawnia rozbieżności, które wskazują na kontrolę własnego wizerunku w komunikacji. Tu nie znajdujemy jednak zbyt wiele dowodów na to, aby ujawnianie własnych ocen było w jakiś sposób korygowane w odniesieniu do ujawniania przypuszczeń, co o postaci papieża myślą inni ludzie. Może to wskazywać na spójność i jednak pewną niekontrowersyjność wizerunku Franciszka. Badani przypisują bowiem innym i sobie podobne skojarzenia, nie przenoszą na innych ocen wrogich, negatywnych, dyskwalifikujących, które być może sami formułują, ale $\mathrm{z}$ jakichś powodów nie chcą ich ujawnić i nie chcą być $\mathrm{z}$ nimi identyfikowani. Poza listą już wcześniej wskazanych wartości jako pewne novum pojawia się odniesienie do kategorii władzy, wskazywanie wieku jako elementu negatywizującego wizerunek papieża: stary, starszy pan (być może wykluczone $\mathrm{z}$ autodeklaratywów w związku z kontrolą wizerunku w odniesieniu do negatywizowanych skojarzeń ageistowskich). Pojawia się także przypisywane innym skojarzenie z kategorią kontrowersyjności, która nie pojawiła się wcześniej. Tu, moim zdaniem, mielibyśmy do czynienia z sygnałem dostrzegania tego, że Franciszek nie jest postacią jednoznacznie pozytywnie ocenianą, że pełna identyfikacja z jego wizerunkiem, który wartościuje się pozytywnie, nie jest powszechna. Wyraźniej problemy wizerunkowe w tym obszarze zarysowują się w odpowiedziach na kolejne pytania, jeszcze o tym szerzej napiszę.

Bardzo ciekawy jest zestaw odpowiedzi, które ujawniły się podczas wskazywania tych treści i wątków nauczania papieża, które respondenci klasyfikowali jako stanowiące podstawowe pozytywne (pytanie: Papież Franciszek jest za...) oraz negatywne (Papież Franciszek jest przeciw...) składniki nauczania, pedagogiki i perswazji papieża. Wydaje się, choć trudno to udokumentować odniesieniem do innych badań czy danych sondażowych, że trafność i przyleganie tych wskazań do realnego wykładu Franciszka i postaw, które prezentuje w treści swojego nauczania, są bardzo wysokie. Respondenci wykazują tu, że treści przesłania Franciszka, podstawowe prawdy, które głosi, i ich interpretacje są skutecznie przekazywane i propagowane przez (chyba przede wszystkim) przekaz medialny. Trudno bowiem wyobrazić sobie, aby program katechetyczny mógł w tak szybkim tempie włączyć do treści nauczania szkolnego przesłania papieża Franciszka (respondenci są zresztą studentami lub osobami, które ukończyły już edukację, nie dotyczy ich przekaz katechetyczny). W polskiej rzeczywistości homiletycznej, realizacji urzędu nauczycielskiego lokalnego Kościoła znajdziemy też zdecydowanie więcej przykładów na pomijanie, redukowanie czy też dystansowanie się od linii nauczycielskiej Bergoglio niż jej entuzjastyczne propagowanie. Stąd moje przypuszczenie, że przekaz Franciszka dociera do odbiorców głównie przez media (raczej świeckie), co samo w sobie jest już mocnym dowodem na skuteczność obranej i realizowanej przez niego linii komunikacji i kształtowania wizerunku. Media muszą bowiem pokazywać i relacjonować treści nauczania papieża w tonie pozytywnym, ustawiać je jako pewnego rodzaju ważący, ważny i atrakcyjny głos, skoro staje się on dość powszechnie rekonstruowany przez respondentów. 
Bardzo wyraźnie dostrzegalną cechą doboru wartości wskazywanych przez respondentów jako te, które w głównej mierze charakteryzują działania i nauczanie Franciszka, jest dobór tych, które zapewne sami udzielający odpowiedzi uważają za podstawowe problemy, z którymi mierzy się instytucja Kościoła: zdyscyplinowanie kleru, interwencje w miejscach konfliktów, działanie na rzecz utrzymania lub przywrócenia pokoju między narodami, występowanie przeciwko luksusowi, w jakim żyje kler, skoncentrowanie wysiłków na rzecz materialnej pomocy biednym. Wskazuje się, że Franciszek działa na rzecz pojednania i łączenia ludzi różnych poglądów i nacji, po ludzku traktuje ateistów, intensywnie działa na rzecz przejrzystych procedur związanych $\mathrm{z}$ uporządkowaniem moralnego życia kleru oraz nakładania na duchownych kar za występki, nie potępia homoseksualizmu („kim jestem, aby oceniać"), a swoją postawą i zachowaniem wyraża uznanie wobec postępu technologicznego (oswaja go, przez akceptację i intensywne korzystanie z narządzi nowoczesnej technologii pokazuje wartość pozytywną).

Bardzo ciekawie przedstawia się druga strona układu pytań dotyczących merytorycznych działań i treści nauczania papieża Franciszka. Poddaje w wątpliwość to, co napisałem, gdyż pokazuje, jak mocny jest wpływ dyskursu kaznodziejskiego i urzędu nauczycielskiego Kościoła lokalnego wspieranego też w lokalnych realiach przez część sceny politycznej, dyskurs katechetyczny i dużą część polskich mediów. Najważniejszym elementem pojawiającym się we wskazaniach dotyczących negatywnych ocen tego, co jest dla papieża Franciszka podstawowym wyzwaniem godnym piętnowania i negatywizowania, jest aborcja. W oficjalnych wystąpieniach Franciszka, także w jego aktywności kaznodziejskiej czy w relacjach z mediami, kwestia aborcji, jeśli się pojawia, z natury sprawy i doktryny katolickiej, jest oczywiście konsekwentnie negatywizowana. Trudno byłoby jednak uznać, że jest to kwestia stanowiąca najbardziej eksponowany, najistotniejszy wątek kaznodziejski Franciszka. Poprzednicy odnosili się do problematyki świętości życia zdecydowanie częściej, angażowali i swój autorytet, i urząd nauczycielski Kościoła w aktualizowanie wykładu na temat niedopuszczalności aborcji. Papież Franciszek, nawet gdy bardzo wyraźnie angażuje się w problematykę rodziny, przewartościowuje ją i inaczej stawia akcenty, więcej miejsca zostawia na sprawy związane z relacjami małżonków, na traktowanie przez wspólnotę Kościoła osób rozwiedzionych, żyjących w powtórnych związkach, związków niesakramentalnych czy związków jednopłciowych. Gdy odpowiada na pytania, przewartościowuje tę problematykę, podkreślając niebezpieczeństwo obsesyjnego wprost skupiania się na problemach prokreacji, cielesności i seksu.

W odpowiedziach na pytanie o to, jakie obszary są dla papieża Franciszka głównymi polami walki, respondenci niezwykle wyraźnie wskazują nie tylko aborcję, lecz także eutanazję oraz antykoncepcję (jako te, które papież potępia). Wydaje się, że świadczy to wyraźnie o trwałości dyskursu krajowego, lokalnego, nakładaniu się tego, co w nauczaniu i duszpasterstwie w Polsce zaprząta serca i umysły księży, a co ma chyba przede wszystkim paralele i zakorzenia się w tych tematach, które i zdecydo- 
wanie częściej pojawiały się, i chętniej były na polski użytek eksponowane w nauczaniu papieża Jana Pawła II. Ta nieprzystawalność kategorii wskazywanych jako te, za których promowaniem, rozwojem opowiada się Franciszek oraz które ukazuje jako istotne i palące kwestie współczesności (nie ma wśród nich wskazań dotyczących świętości życia czy promowania cywilizacji życia versus cywilizacji śmierci) jest nie tylko klarowna, ale też instruktywna. Pokazuje, że papież jest słuchany wybiórczo, a w wielu momentach nakłada się na jego spójny przekaz projekcja wdrukowanych stereotypów i klisz (papiestwo musi być przeciw aborcji, eutanazji, antykoncepcji, nawet jeśli papież o tym nie mówi, to i tak o tym mówi).

Liczne odpowiedzi świadczą jednak o pewnej spójności budowanego wizerunku Franciszka: respondenci (nie tak często, jak to ma miejsce w powyżej wskazanych kwestiach) wskazują, że podstawową linią walki ideowej papieża jest koncentrowanie wysiłków na zmianę postawy i mentalności kleru katolickiego, szczególnie jeśli chodzi o gromadzenie bogactw doczesnych. Odpowiadający piszą więc, że Franciszek jest przeciw marnotrawieniu pieniędzy, bogactwu księży, niepotrzebnemu bogactwu, epatowaniu bogactwem przez księży. Łączą te działania z postawą antyeksluzywistyczną - Franciszek jest przeciw zamykaniu się Kościoła na wiernych, przeciw „katolskiemu" podejściu. Pojawiają się też istotne, ale zdecydowanie jednostkowe wskazania odnośnie do charakterystycznego dla poprzedników, tu jednak mniej szacowanego, kursu dotyczącego przeciwstawiania się pedofilii w Kościele. Jest to o tyle istotne, że nie tylko dyskurs medialny, lecz także działania podejmowane $\mathrm{z}$ własnej inicjatywy lub jako reakcja na kolejne kryzysy wizerunkowe i informacyjne ze strony hierarchii Kościoła lokalnego w Polsce wskazywałyby na uważniejsze poszukiwanie i dostrzeganie w postawie i nauczaniu aktualnego papieża wątków odnoszących się do istniejącej w polskiej sytuacji społecznej kwestii, jaką są morale kleru, w tym kwestia pedofilii. Respondenci nie dostrzegają jednak w postawie i pedagogii Franciszka wyraźnych rysów odnoszących się do tej problematyki, wskazują ją jednak bardzo rzadko, negatywizowane cechy kleru łącząc de facto prawie wyłącznie z potępianym przez Franciszka upodobaniem do bogactwa materialnego, życia w luksusie i egotycznego uwielbienia.

Metodyka badania nakazuje wrócić do spraw związanych $\mathrm{z}$ autodeklaratywami ze strony badanych. Stąd w kolejnym pytaniu pojawia się znów kwestia wizerunku Franciszka (pytanie: jaki jest papież Franciszek?). Wszystkie uzyskane odpowiedzi są pozytywne, respondenci wskazują albo na postawę, pejzaż mentalny i nauczanie papieża, albo na cechy charakteru wyraźnie kierujące ku budowaniu wspólnoty, składające się na wizerunek osoby empatycznej, otwartej, przyjaznej, budzącej zaufanie i po prostu sympatycznej ( $z$ dozą szacunku, nie ma tu raczej miejsca na pewien protekcjonalizm czy nieuzasadnione pozytywne emocje, sama postawa i aktywne działanie Franciszka są zakładem, który zdobywa mu przychylność odbiorców). Otrzymujemy więc wskazania, że Franciszek jest: skromny, franciszkański (tu zapewne pojawiają się skojarzenia z prostotą i ubóstwem przypisywanym poprzez nurt kultury popularnej postaci i postawie św. Franciszka z Asyżu). Respondenci dodają, że jest to osoba 
otwarta, tolerancyjna, spokojna, przyjazna, życzliwa, pogodna, taka, która przyciąga, a nie odrzuca, jest za tradycją, ale jest postępowy. Warto podkreślić, że każda z tych wartości wyraźnie zakłada aktywność i działanie przeradzające się w efekt, jakim jest rozumienie i akceptacja wysiłku komunikacyjnego przez otoczenie.

Seria odpowiedzi na pytanie, które miało wyodrębnić Franciszka i jego wizerunek $\mathrm{z}$ ciągu wizerunków biograficznych postaci reprezentujących w postrzeganiu respondentów ludzi Kościoła katolickiego (pytanie: czym papież Franciszek różni się od innych papieży [przedstawicieli Kościoła]?), łączy kilka bardzo ciekawych poznawczo wątków. Z jednej strony bardzo konsekwentnie wracają i ujawniają się jako differentia specifica odniesienia do skromności, manifestowanej nie tylko werbalnie powściągliwości materialnej, prowadzenia normalnego życia, rozumianego tutaj zapewne jako bardzo wyraźny proces desakralizacji postaci papieża jako osoby i funkcji. Trudno byłoby zakładać, że respondenci mają na myśli realne skutki podejmowanych przez poszczególnych papieży działań i podejmowanych decyzji, gdy piszą, że Franciszek nie jest tak radykalny jak Benedykt XVI. Wydaje się, że ów radykalizm byłby tu odnoszony do kwestii konserwatyzmu obyczajowego, teologicznego, duszpasterskiego czy liturgicznego. Samo przecież złożenie przez Josepha Ratzingera urzędu było decyzją tak niezwykle postępową i radykalną (ono przecież było realnym znakiem zakwestionowania dotychczasowej wielowiekowej, choć nie nieprzerwanej opowieści Kościoła o papieżu jako namiestniku Chrystusa na Ziemi). Respondenci zwracają uwagę na aktywność medialną Franciszka, manifestowaną i używaniem technologii i odczarowaniem tej sfery (tu warto podkreślić, że zarówno Jan Paweł II, jak i Benedykt XVI używali nowych technologii, a także wskazywali na ich dobre strony, wydaje się jednak, że czynili to na tyle wyraziście i spektakularnie, na ile ówczesna kultura medialna na to pozwalała, nie stawiając papieży w sytuacji niezręcznej, wskazującej na czynienie z użycia technologii kolejnego dowodu na diachroniczność posługi, oderwanie od otoczenia, nienadążanie za rzeczywistością wiernych). Franciszek nie celebruje tego obszaru, traktuje go jako pewną oczywistość (tak jak traktują go odbiorcy), ci więc zauważają właśnie tę wartość, bycia bliskim ludziom, prowadzenia zwyczajnego życia (wpisując zapewne w tę zwyczajność to, że ma konto na Twitterze, robi sobie selfie i jest dla niego naturalne, że wymaga ono zabawnej, wesołej mimiki).

Istotnym elementem konstruktu wizerunkowego Franciszka wydaje się przyporządkowanie odpowiednio definiowanych cech jako elementów stanowiących atuty lub obciążenia wizerunkowe samej postaci. Stąd pytanie o mocne strony papieża Franciszka układa się w szereg wskazań frekwencyjnie w przewadze odnoszących się do konstytucji osobowej Franciszka (skromny, spontaniczny, cierpliwy, dobroduszny, sympatyczny), które moglibyśmy też w pewnym stopniu uznać za co prawda dające się ukształtować i wypracować, ale też niejako wrodzone. $\mathrm{Z}$ drugiej strony znacznie mniej wskazań znajdujemy po stronie takich charakterystyk, które ukazują pewne komunikacyjne i formalne właściwości: sprawiedliwy, postępowy, uczynny (niosący innym pomoc). Jako główną wadę (słabą stronę) osoby, a de facto nie tyle wizerunku, co 
zapewne komponentu myślenia o sile sprawczej i pewnego chciejstwa respondentów co do potencji sprawczej papieża, wskazuje się cechę obiektywną — wiek (stary). Pojawiają się także elementy pośrednio wskazujące na słabości nie tyle właśnie samego papieża, co położenia, w którym się on znajduje: mała siła przebicia, osamotniony w Watykanie, nie ma wsparcia. Układają się te wypowiedzi w dość konsekwentny zbiór: zabezpieczają wizerunek postaci na okoliczność ewentualnej porażki, dając od razu klucz do interpretacji jej przyczyn. To nie nieskuteczność czy nieudolność Franciszka (lub po prostu nietrafne definiowanie potrzeb i problemów Kościoła) mogą być przyczyną jego porażki. Będzie nią bowiem jego osamotnienie, pewne samospełniające się proroctwo, samousprawiedliwiająca się klęska, która musi nadejść. W odpowiedziach respondentów daje się także wychwycić ciekawy wątek poznawczy; niektórzy piszą bowiem, że Franciszek jest papieżem w czasach „gdy Kościół jest bardzo szykanowany, gdy wychodzi na jaw mnóstwo skandali”. Jakby na jednym oddechu dawało się połączyć z sobą te dwa zjawiska, zostawiając sobie pole do ostatecznego rozstrzygnięcia, czy Kościół jest ofiarą (szykan), czy sprawcą (skandali), czy niesłusznie jest prześladowany, czy odpowiednio do win swoich członków zbiera żniwo niecnej działalności.

Obrana przez Jorge Bergoglio $\mathrm{w}$ pierwszych godzinach pontyfikatu strategia komunikacyjna, eksponująca kategorię skromności jako tę, która stać się powinna signum tempori pontyfikatu, okazuje się bardzo skuteczna i trafna. Respondenci pytani o to, co jest dla papieża w jego aktywności priorytetowe, wymieniają najczęściej właśnie skromność, skromne wykonywanie funkcji papieża. Przenoszą niejako deklaratyw werbalny, którym posłużył się Joseph Ratzinger, gdy obejmował stery nawy kościelnej, mówiąc, że jako skromny robotnik winnicy Pańskiej przychodzi po czasach Wielkiego Papieża.

Projekcja samego siebie rzutowana na grupę kategoryzującą się pozytywnie to w wypadku obrazu zwolenników papieża Franciszka niezwykle dodatnio wartościowany zbiór. Popierają go wierzący (cokolwiek by to dla respondentów znaczyło, na pewno jest to określenie pozytywne), pojawia się także w inwariancie bardzo wierzący. Uznaję je za określenie pozytywne, gdyż nie pojawia się w kolokacjach negatywnych: oczadziali, fanatyczni, skrajni. Bywa, że pojawia się dopełniająca konstrukcja: wierzący, którzy chcą zmian. Respondenci piszą o zwolennikach Franciszka, że są to szczerzy i dobrzy ludzie, otwarci, dbający o rozwój Kościoła, postępowi, normalni, młodzi, mądrzy, ci, którzy chcą czystego Kościoła bez skandali, mocno wierzący, ale też - co znowu wskazuje na trwałość konstrukcji wizerunkowej — biedni.

Wizerunek Franciszka jest jednocześnie ustabilizowany i złożony. Jego rekonstrukcja świadczy o pewnym oceniającym dystansie respondentów, o ich trafnej deskrypcji i ocenie nie tylko komunikacji perswazyjnej, lecz także elementów o charakterze i wartości merytorycznej. Dowodzi tego rozkład wartości badany z wykorzystaniem dyferencjału semantycznego. Zależało mi, aby wykazać, w jakim stopniu w postrzeganiu respondentów Franciszek jest zorganizowany, a w jakim chaotyczny; czy jest nowoczesny, czy tradycyjny, innowacyjny czy konserwatywny, godny czy niegodny 
zaufania, sympatyczny czy niesympatyczny, sprawiedliwy czy niesprawiedliwy. Cechy zostały dobrane na podstawie głównych wątków semantycznych, które możemy wyodrębnić w komunikacji Franciszka.

Respondenci są zgodni, gdy pyta się ich o to, czy Franciszek jest sympatyczny jest to jego główna pozytywna cecha, nie ma bowiem odpowiedzi innych niż w skali dwóch lub trzech tej cechy jako charakteryzującej wizerunek. Podobnie w wypadku cechy aktywności, jaką jest sprawiedliwość, między jedną a trzema zamykają się niemal wszystkie odpowiedzi dotyczące postrzegania wizerunku papieża Franciszka. W odpowiedziach respondentów pojawia się wysokie natężenie cechy „godny zaufania”, mimo rzadkich wskazań odsyłających do braku zaufania. Co ciekawe, bardzo podobnie lokują się odpowiedzi dotyczące zestawienia komponentów: zorganizowany/chaotyczny. Mimo pojawiających się w innych miejscach ankiety odpowiedzi wskazujących na spontaniczność, pewne niepoukładanie czy brak jednoznacznej strategii działań, papież jest postrzegany jako zorganizowany.

Kluczowe w tej części badania - trudno tu jednoznacznie stwierdzić, czy dla wizerunku Franciszka, czy dla kompetencji respondentów - są odpowiedzi lokujące w skali dyferencjalnej opozycje: nowoczesny/tradycyjny oraz innowacyjny/konserwatywny. W obu wypadkach odpowiedzi odnoszące się do większego natężenia cech przyznają dominację komponentom tradycyjny i konserwatywny.

W całym badaniu układ prowadzący do wskazania przez respondentów tych dwóch cech jako dominujących i najsilniej się manifestujących w wizerunku Franciszka wydaje mi się kluczowy. Udowadnia on, że komunikacja dotycząca personalnego wizerunku postaci to jedno, natomiast trafna deskrypcja i ocena nauczania papieża to drugie. Jednoznaczne wskazanie przez respondentów jako cech dominujących komponentów odnoszących się do tradycjonalizmu i konserwatyzmu w największej mierze mają związek z identyfikowaniem konstruktu wizerunkowego aktualnego papieża $z$ instytucją konfesyjną (tradycjonalistyczną i konserwatywną), także z postrzeganiem tych wartości przez pryzmat raczej instytucjonalny, ekstrapolowania ich w pola semantyczne związane z przywiązaniem do sfer wartości, uznanych kulturowo hierarchii i porządków struktur społecznych, rodzinnych, grupowych. Respondenci nie tyle dyskwalifikują swoje wcześniejsze opinie o wizerunku papieża, co pokazują, że nie przekładają się one na postrzeganie i wartościowanie ogólnego przekazu, który dociera do opinii publicznej. Papież jest reprezentantem konserwatywnej instytucji, sam też jest konserwatystą, ale takim, który umiejętnie posługuje się narzędziami nowoczesnej cywilizacji. Uczestnicy badania pokazują swoimi odpowiedziami także, co według nich należy, a co nie należy do obszaru pojęciowego "tradycjonalizm” i „konserwatyzm”, nie odnosząc się negatywnie do tych kategorii. Papież konserwatysta może być - i jest - lubiany, akceptowany, przywodzi sympatyczne skojarzenia. Respondenci, bo chyba w większym stopniu odpowiedzi mówią o nich, a nie o Franciszku, okazują się bardzo kompetentnymi odbiorcami skutecznie budowanej komunikacji papieża spoza Europy. 


\section{Pope Francis. What is he like, how do we perceive him? Image in confessional communication}

\section{Summary}

The article combines descriptive data on the development, shaping and communication of the image of Jorge Bergoglio, from the moment of his election to the papacy and adoption of the name of Francis, with the author's own research into the assessment and perception of Pope Francis. The author analyses the results of research into the evolution and evaluation of Pope Francis' personal image, and points to the most important elements of the varied opinions on both the figure of the pope and his actions, exercise of social roles, risks and strengths of his image. 